\title{
Implementation Status of Right to Education (RTE) Act 2009 in Andhra Pradesh: An Empirical Analysis
}

\author{
A. Hari Krishna ${ }^{1}$, K. Ravi Teja ${ }^{2}$ and K. Ravindra ${ }^{3}$ \\ ${ }^{1}$ Lecturer in Political Science, S.V.R.M. College, Nagaram, Guntur, Andhra Pradesh, India \\ ${ }^{2}$ Lecturer in Political Science, The Hindu College, Machilipatnam, Andhra Pradesh, India \\ ${ }^{3}$ Post-Doctoral Fellow, Dept. of Economics, Andhra University, Visakhapatnam, Andhra Pradesh, India \\ "Corresponding author: projectsvsp@gmail.com
}

Received: $10-10-2019$

Revised: $17-02-2020$

Accepted: 27-03-2020

\begin{abstract}
The purpose of the present research is to examine out implementation status of Right to Education (RTE) Act 2009 in Andhra Pradesh. The study also embodied a sizeable primary data, which is collected by way of canvassing a questionnaire among selected respondents. The data was collected in public and private schools in two selected Districts of Andhra Pradesh. Based on the key indicators of elementary education, one dominated performed district and one meager performed district in Andhra Pradesh state were selected for sample of the study. According primary data analysis, the enrollment status is quite satisfactory under RTE regime while the pupil-teacher ratio is 1:11, which is not as per RTE norms. During RTE three is improvement in physical infrastructure and human resources, besides effective implementation of the Act is obligatory. The study reveals that majority of students responded positively regarding Teaching Learning - Quality Indicators and provisions. It is observed from the teacher's response, majority of sample schools constituted School Management Committee and the schools management also satisfied with the functioning of School Management Committee. Majority of schools have held Parent-TeacherStudent (PTS) meetings and the frequency of PTS meetings is once in year. The RTE Act has met with success in achieving some of the goals with which it started in the year 2010. Many of the states have been successful in ensuring RTE recommendations. Besides the success of RTE Act, the present study has found gaps in elementary education after its implementation.
\end{abstract}

Keywords: Primary Education, Upper Primary Education \& Right to Education Act

The moral foundations of Right to Education are laid down in the Universal Declaration of Human Rights. Globally, right to education derives its legal basis from Article 26(1) of the Universal Declaration of Human Rights, which states that "Everyone has the right to education. Education shall be free, at least in the early and elementary stages. Elementary education shall be compulsory (UDHR, 1948). European Convention on Human Rights (1952) protected basic human right to education; no person shall be denied the right to education. Convention against Discrimination in Education (1960) declared under Article 4(a), makes primary education free and compulsory. International
Covenant on Economic, Social and Cultural Rights (1966) stated under article 13 of the right of everyone to education. CEDAW (1979) article 10 guarantees their right to education. It promotes gender equality endowing every woman with equal rights as those of man in the field of education, from pre-school to higher technical education. Convention on the Rights of the Child (1989) recognised education as a legal right to every child on the basis of equal opportunity. ASEAN Human Rights Declaration (2012) under article 31 provided every person has the right to education. With above scenario, right based approach to development the paradigmshift on the importance of Right to Education. The 
enforcement of compulsory education Act globally, a demand was raised, in India, to provide similar act for Right to Education (Nalini, 2003). The Right of Children to Free and Compulsory Education Act or Right to Education Act (RTE), which was passed by the Indian parliament on $4^{\text {th }}$ August 2009, made India one of 135 countries to make education a fundamental right of every child. In 2002, the government of India took a significant step by making elementary education a fundamental right through the $86^{\text {th }}$ Constitutional Amendment. In 2009, India went further and passed the Right of Children to Free and Compulsory Education Act. The evolution of Free and Compulsory Education landscape in India presented in brief in below table.

Table: Evolving Free and Compulsory Education Landscape in India

\begin{tabular}{|c|c|c|}
\hline Time & Elementary education & Across segments \\
\hline $\begin{array}{l}1951- \\
1974\end{array}$ & $\begin{array}{l}\text { Expansion of basic and } \\
\text { elementary education (First } \\
\text { Plan - 1951-56) Primary } \\
\text { education made free and } \\
\text { compulsory (Fourth Plan - } \\
\text { 1969-74) }\end{array}$ & $\begin{array}{l}\text { First National Policy } \\
\text { on Education adopted } \\
(1968)\end{array}$ \\
\hline $\begin{array}{l}1974- \\
1990\end{array}$ & $\begin{array}{l}\text { Launch of centrally assisted } \\
\text { schemes such as Operation } \\
\text { Blackboard (1986), Non- } \\
\text { formal education scheme } \\
\text { (1986), Shiksha Karmi } \\
\text { Project (1987) and Mahila } \\
\text { Samakya (1989) }\end{array}$ & $\begin{array}{l}\text { Launch of integrated } \\
\text { child development } \\
\text { scheme (ICDS) for } \\
\text { children up to six } \\
\text { years of age (1975) } \\
\text { Education made a } \\
\text { concurrent subject } \\
\text { (1976) Second } \\
\text { National Policy on } \\
\text { Education adopted } \\
(1986)\end{array}$ \\
\hline $\begin{array}{l}1990- \\
2011\end{array}$ & $\begin{array}{l}\text { District Primary Education } \\
\text { Programme launched } \\
\text { to universalize primary } \\
\text { education (1994) Mid- Day } \\
\text { Meal scheme (1995) } \\
\text { Sarva Shiksha Abhiyaan } \\
\text { launched (2001) }\end{array}$ & $\begin{array}{l}\text { NPE } 1986 \text { revised } \\
\text { based on review by } \\
\text { Acharya Ramamurti } \\
\text { Committee (1992) } \\
\text { Constitution } \\
\text { amended to make } \\
\text { Free and Compulsory } \\
\text { Education a } \\
\text { fundamental right } \\
\text { (2002) } \\
\text { Right to Education } \\
\text { Act (2009) }\end{array}$ \\
\hline
\end{tabular}

Source : Right to education: role of the private sector, 2012, Ernst $\mathcal{E}$ Young Pvt. Ltd, Kolkata.

The first time in the history of India a law was brought into force by a speech by the Prime Minister. In his speech, Manmohan Singh, the Prime
Minister of India stated that, "We are committed to ensuring that all children, irrespective of gender and social category, have access to education. An education enables them to acquire the skills, knowledge, values and attitudes necessary to become responsible and active citizens of India" (Kamalakar \& Bhojanna, 2012).No matter how well a policy in written on paper, the success of a policy depends largely on how well it is implemented (Calland, 2010). The RTE Act is a detailed and comprehensive piece of legislation which includes provisions related to schools, teachers, curriculum, evaluation, access and specific division of duties and responsibilities of different stakeholders (Hussain et al. 2014). However, there is an important concern over implementation of RTE Act in the school system with reference to the training or instruction, its modalities and execution. States and UTs are required to pay special attention to cope with the situation in terms of appointment of qualified teachers, development of special training programmes for out-of- school children admitted to age appropriate classes and preparation of relevant teaching learning materials for them (Soni, 2013).

Though, the Act introduces several positive features which, if implemented, can bring about longpending improvements in the school education system of India. These include: upgrading of infrastructure, recruitment of additional teachers in order to comply with the prescribed pupil-teacher ratio of 30:1 at the primary level, making education free, enrolment of all out-of-school children, constitution in each school of democratically elected school management committees, and doing away with screening procedure and capitation fee for admission of children and with private tuition by teachers (RTE Forum, 2012). RTE Act fulfills the constitutional mandate for free and compulsory primary education but some of its provisions have raised debates over the years. Various challenges and issues are being faced by stakeholders in implementing this Act in the schools (Banerjee \& Arora, 2013). Though, the states are paying special role on RTE implementation number of constraints and Challenges faced by RTE while implementation.

\section{LITERATURE REVIEW}

Jha \& Parvati (2010) studied critical gaps and challenges Right to Education Act 2009. After the 
many rounds of drafting and redrafting that went into the Right of Children to Free and Compulsory Education Act of 2009, it was hoped that the Act would be an effective instrument for any child to demand her basic entitlement. Yet, a close look at the provisions reveals confusing features. Reddy \& Sinha (2010) explored data and research literature related to school dropouts, overcoming barriers for the Right to Education. Persistently high dropout rates are one of the biggest challenges to fulfilling the right to education in India. Bhan \& Rodricks (2012) analyzed the feasibility of RTE and highlight the challenges in its implementation in India, They found that the attitudinal barriers, lack of awareness of the legal provisions and subsequent schemes, accessibility of schools being meager, lack of necessary infrastructure, lack of and retention of trained staff adaptation of curriculum and materials and lack of control systems. Kaushal (2012) founds that although serious barriers and roadblocks in way desired objectives of 86th Constitutional Amendment Act. These issues need to be addressed on an urgent basis to strengthen the scene of education at the grassroots level. Soni \& Rahman (2013) made an attempt to find out the status of implementation of various provisions of RTE Act 2009. The results revealed that the States/ UTs were implementing provisions of RTE Act, 2009 to a great extent and efforts were being made to implement various provisions of the Act. Agrawal (2013) analyzed educational attainment in backward states of India with reference to Right to Education Act. The results were very distressed for disadvantaged social groups of the society. Sarin \& Gupta (2014) verified quotas under the Right to Education Act, 2009. The quotas have imposed a debate on issues of social integration and equity in education that private actors had by and large escaped so far. Thakur (2014) studied the level of awareness on RTE act in relation to trained school teachers. Results revealed that the level of awareness on RTE act was poor, there was no significant difference in the level of awareness in relation to RTE act among the male and female trained teachers and there was a significant difference between the urban and rural trained teachers. Cheruvalath (2015) examined whether the Right of Children to free and Compulsory Education Act can achieve its objective of ensuring education for all children in India. He found the miserable fact is that the Right of Children to Free and Compulsory Education Act will not help to bring the poorer children into the main arena of education, in fact, the poor souls are nowhere in the picture and only a few lower middle-income people will be benefitted from the act. Malakar \& Mahato (2015) studied implementation status of Right to Education (RTE) Act 2009. According to them, after implementation of RTE a lot of improvement has been achieved. Mehendale et al. (2015) conducted a study on Right to Education and inclusion in private unaided schools. It concludes by identifying gaps and challenges that require an urgent policy response. The applicability of this provision to certain types of schools, such as those affiliated to international boards and residential schools is ambiguous. Chauhan \& Sati (2016) carried out a study to know about the status of RTE in Uttarakhand after such long period of its implementation. This study concluded that RTE at present is not at satisfactory level after such long period of implementation. Mahajan (2016) aimed at examining the status of implementation of right to education act in the context of drinking water and sanitation facilities and found that in pre RTE $97.26 \%$ of the primary schools of Himachal Pradesh were equipped with the drinking water facility which further increased to $99.88 \%$ during post RTE. Dutta \& Khan (2017) examined educational and social inclusion of children admitted under RTE Quota. The results revealed that students admitted under EWS quota in private schools are being mainstreamed and socially included into the private schools but the process of social and educational inclusion is not smooth. Sucharita \& Sujatha (2019) studied the social inclusion through RTE. It was found that the children admitted under this provision have not satisfactory.

In spite of the implementation of RTE, the goal of achieving universal primary education by 2019 seems unsatisfactory in some cases for India. After crossing eight years of its implementation, it remains to be seen whether the Act has been implemented well enough to make a significant impact in the lives of children. In this context, this research paper was analyzed the implementation status of Right to Education Act 2009 in Andhra Pradesh.

\section{Objective}

The main objective of the study is to analyze the 
implementation status of Right to Education Act 2009 at grassroots. The specific objectives of the study are to find out the status of implementation of various provisions of Right to Education Act 2009 and to evaluate or assess the performance of schools in the sample areas after implementation of Right to Education Act. To analyze the implementation status, the study has undertaken various parameters like enrolment, Pupil to Teacher Ratio (PTR), infrastructure facilities, separate toilets for girls and boys, school management committee and teachers parents meetings.

\section{Methodology}

The study also embodied a sizeable primary data, which is collected by way of canvassing a questionnaire among selected sample of respondents. The data was collected in public and private schools in two selected Districts of Andhra Pradesh. Based on the key indicators of elementary education, one dominated performed district and one meager performed district in Andhra Pradesh state are selected for sample of the study. From the selected districts, one Mandal selected from each one which comprises rural and urban segments. From each Mandal, public and private schools from rural and urban areas are selected with simple random sampling. From each school, one head teacher/teacher and two pupils are selected as respondents. The sample comprises teachers and children studying in primary classes and upper primary classes.

At first stage, two districts from Andhra Pradesh state namely Guntur and Srikakulam districts are selected. Second stage of sampling is selection of Mandal, Tenali Mandal from Guntur district and Amadalavalasa Mandal from Srikakulam district are selected. In the third stage, from Tenali Mandal 207 (177 primary and 30 upper primary) schools and from Amadalavalasa Mandal 173 (141 primary and 32 upper primary) schools are selected. The last stage of sampling is the selection of respondents. From each school, 380 members form teachers and 760 members from students are selected as respondents for interview. Data collected through interviews, observations and school information sheet are tabulated, interpreted and presented in a concise format.

\section{RESULTS AND DISCUSSION}

\section{Basic Indicators}

Distribution of sample schools by management is revealed that out of 318 primary schools, 86.5 percent schools are under government management followed by 13.5 percent under private management. Out of 62 upper primary schools, 64.5 percent schools come under the government management and 35.5 percent private management. Considering the total sample schools, 82.9 percent schools are observed under government management and the remaining 17.1 percent schools are under private management (Table 1).

The distribution of enrolment by management in sampled schools in the study area is confirmed that out of the total enrolment (13335) about 55.1 percent is recorded in government schools and 44.9 percent in private schools. In primary schools, the composition of enrolment in government and private schools is 58.9 percent and is 41.1 percent. In the case of upper primary schools, the composition of enrolment in government schools is 43.6 percent and the composition of enrolment in private schools is 56.4 percent. The total enrolment in primary schools is 5194, out of which the highest share of 58.4 percent is observed in government schools and the remaining share of 41.6 percent in private schools. The total enrolment in upper primary schools is 1485 , out of which the prime share of 39.4 percent is observed in government schools and the remaining share of 60.6 percent in private schools. The composition of enrolment in government schools is 59.5 percent and in private schools the enrolment is 40.5 percent. The total enrolment in upper primary schools is 1806 , the composition of enrolment in government schools is 47.1 percent and in private schools the enrolment is 52.9 percent (Table 2).

The picture of enrolment based on social community is disclosed that in Primary Schools the enrolled students are 10044, out of which 43.3 percent belongs to BC community followed by SC community $(23.9 \%)$, OC community (13.7\%), ST community $(10.0 \%)$ and minorities $(9.1 \%)$. According to Table 3 , BC community has occupied the first place followed by SC community and OC community in two sample Mandals. Out of the total enrolled students in upper primary schools are (3291), about 
Table 1: Distribution of Selected Schools by Management

\begin{tabular}{|c|c|c|c|c|c|c|c|c|c|c|}
\hline \multirow{2}{*}{$\begin{array}{l}\text { Sl. } \\
\text { No. }\end{array}$} & \multirow{2}{*}{$\begin{array}{c}\text { Name of the } \\
\text { Mandal }\end{array}$} & \multicolumn{3}{|c|}{ Primary } & \multicolumn{3}{|c|}{ Upper Primary } & \multicolumn{3}{|c|}{ Total } \\
\hline & & Govt. & Private & All & Govt. & Private & All & Govt. & Private & All \\
\hline 1 & Tenali & $\begin{array}{c}148 \\
(83.6)\end{array}$ & $29(16.4)$ & 177 (100.0) & $18(60.0)$ & $12(40.0)$ & $30(100.0)$ & $166(80.2)$ & $41(19.8)$ & $207(100.0)$ \\
\hline \multirow[t]{2}{*}{2} & Amadalavalasa & $\begin{array}{c}127 \\
(90.1)\end{array}$ & $14(9.9)$ & $141(100.0)$ & $22(68.8)$ & $10(31.2)$ & $32(100)$ & $149(86.1)$ & $24(13.9)$ & $173(100.0)$ \\
\hline & Total & $\begin{array}{c}275 \\
(86.5)\end{array}$ & 43 (13.5) & $318(100.0)$ & $40(64.5)$ & $22(35.5)$ & $62(100.0)$ & $315(82.9)$ & $65(17.1)$ & $380(100.0)$ \\
\hline
\end{tabular}

Source: Computed from Primary Data.

Table 2: Distribution of Enrolment by School Management

\begin{tabular}{|c|c|c|c|c|c|c|c|c|c|c|}
\hline \multirow{2}{*}{$\begin{array}{l}\text { Sl. } \\
\text { No. }\end{array}$} & \multirow{2}{*}{$\begin{array}{c}\text { Name of the } \\
\text { Mandal }\end{array}$} & \multicolumn{3}{|c|}{ Primary } & \multicolumn{3}{|c|}{ Upper Primary } & \multicolumn{3}{|c|}{ Total } \\
\hline & & Govt. & Private & All & Govt. & Private & All & Govt. & Private & All \\
\hline 1 & Tenali & $\begin{array}{c}3034 \\
(58.4)\end{array}$ & 2160 (41.6) & $\begin{array}{c}5194 \\
(100.0)\end{array}$ & $585(39.4)$ & $900(60.6)$ & $\begin{array}{c}1485 \\
(100.0)\end{array}$ & $\begin{array}{l}3619 \\
(54.2)\end{array}$ & $3060(45.8)$ & $\begin{array}{c}6679 \\
(100.0)\end{array}$ \\
\hline 2 & $\begin{array}{c}\text { Amadala- } \\
\text { valasa }\end{array}$ & $\begin{array}{c}2885 \\
(59.5)\end{array}$ & 1965 (40.5) & $\begin{array}{c}4850 \\
(100.0)\end{array}$ & $850(47.1)$ & $956(52.9)$ & $\begin{array}{c}1806 \\
(100.0)\end{array}$ & $\begin{array}{c}3735 \\
(56.1)\end{array}$ & 2921 (43.9) & $\begin{array}{c}6656 \\
(100.0)\end{array}$ \\
\hline & Total & $\begin{array}{l}5919 \\
(58.9)\end{array}$ & 4125 (41.1) & $\begin{array}{l}10044 \\
(100.0)\end{array}$ & $\begin{array}{l}1435 \\
(43.6)\end{array}$ & $1856(56.4)$ & $\begin{array}{c}3291 \\
(100.0)\end{array}$ & $\begin{array}{l}7354 \\
(55.1)\end{array}$ & $5981(44.9)$ & $\begin{array}{c}13335 \\
(100.0)\end{array}$ \\
\hline
\end{tabular}

Source: Computed from Primary Data.

Table 3: Caste wise Enrolment to Total Enrolment in Selected Schools

\begin{tabular}{|c|c|c|c|c|c|c|c|}
\hline Sl. No. & $\begin{array}{c}\text { Name of the } \\
\text { Mandal }\end{array}$ & General & O.B.C. & S.C & S.T & Minorities & Total \\
\hline \multicolumn{8}{|c|}{ Primary Schools } \\
\hline 1 & Tenali & 877 (16.9) & $1725(33.2)$ & $1050(20.2)$ & 748 (14.4) & 794 (15.3) & $5194(100.0)$ \\
\hline \multirow[t]{2}{*}{2} & Amadala-valasa & $499(10.3)$ & $2628(54.2)$ & $1348(27.8)$ & $253(5.2)$ & $122(2.5)$ & $4850(100.0)$ \\
\hline & Total & 1376 (13.7) & $4353(43.3)$ & 2398 (23.9) & $1001(10.0)$ & $916(9.1)$ & 10044 (100.0) \\
\hline \multicolumn{8}{|c|}{ Upper Primary } \\
\hline 1 & Tenali & $242(16.3)$ & 395 (26.6) & $346(23.3)$ & $221(14.9)$ & $281(18.9)$ & 1485 (100.0) \\
\hline \multirow[t]{2}{*}{2} & Amadala-valasa & $169(9.4)$ & $890(49.3)$ & $523(29.0)$ & $224(12.4)$ & $0(0.0)$ & $1806(100.0)$ \\
\hline & Total & 411 (12.5) & $1285(39.0)$ & $869(26.4)$ & 445 (13.5) & $281(8.5)$ & $3291(100.0)$ \\
\hline \multicolumn{8}{|c|}{ Total } \\
\hline 1 & Tenali & 1119 (16.8) & $2120(31.7)$ & $1396(20.9)$ & 969 (14.5) & 1075 (16.1) & $6679(100.0)$ \\
\hline \multirow[t]{2}{*}{2} & Amadala-valasa & $668(10.0)$ & 3518 (52.9) & $1871(28.1)$ & $477(7.2)$ & $122(1.8)$ & $6656(100.0)$ \\
\hline & Total & 1787 (13.4) & $5638(42.3)$ & 3267 (24.5) & 1446 (10.8) & $1197(9.0)$ & 13335 (100.0) \\
\hline
\end{tabular}

Source: Computed from Primary Data.

39.0 percent enrolment belongs to $\mathrm{OBC}$ community followed by SC community $(26.4 \%)$, ST community $(13.5 \%)$, OC community $(12.5 \%)$ and minorities $(8.5 \%)$. Out of the total enrolled students in primary and upper primary schools are (13335), around 42.3 percent of students belong to $\mathrm{OBC}$ community followed by SC community $(24.5 \%)$, OC community $(13.4 \%)$, ST community $(10.8 \%)$ and minorities $(9.0 \%)$.

The information of teachers by school management is described that out of the total teachers (1251) about 68.0 percent are working in government schools and 32.0 percent are in private schools. In primary schools, the composition of teaching strength in government schools is 72.9 percent and private schools the enrolment is 27.1 percent. In upper primary schools, the composition of teachers in government schools and private schools is 55.9 percent and 44.1 percent respectively (Table 4 ).

The Pupil Teacher Ratio (PTR) by School management exhibited that the number of students per one teacher. In total sample schools, the PTR is found to be more in private schools (1:15) followed by government schools (1:9) and together (1:11). Same 
Table 4: Distribution of Teachers in Selected Schools by Management

\begin{tabular}{|c|c|c|c|c|c|c|c|c|c|c|}
\hline \multirow{2}{*}{$\begin{array}{l}\text { Sl. } \\
\text { No. }\end{array}$} & \multirow{2}{*}{$\begin{array}{c}\text { Name of the } \\
\text { Mandal }\end{array}$} & \multicolumn{3}{|c|}{ Primary } & \multicolumn{3}{|c|}{ Upper Primary } & \multicolumn{3}{|c|}{ Total } \\
\hline & & Govt. & Private & All & Govt. & Private & All & Govt. & Private & All \\
\hline 1 & Tenali & $372(72.0)$ & $145(28.0)$ & $517(100.0)$ & $97(57.1)$ & $73(42.9)$ & $170(100.0)$ & $469(68.3)$ & $218(31.7)$ & $687(100.0)$ \\
\hline 2 & $\begin{array}{c}\text { Amadala- } \\
\text { valasa }\end{array}$ & $279(74.2)$ & $97(25.8)$ & $376(100.0)$ & $103(54.8)$ & $85(45.2)$ & $188(100.0)$ & $382(67.7)$ & $182(32.3)$ & $564(100.0)$ \\
\hline & Total & $651(72.9)$ & $242(27.1)$ & $893(100.0)$ & $200(55.9)$ & $158(44.1)$ & $358(100.0)$ & $851(68.0)$ & $400(32.0)$ & $1251(100.0)$ \\
\hline
\end{tabular}

Source: Computed from Primary Data.

Table 5: Distribution of PTR in Selected Schools by Management

\begin{tabular}{|c|c|c|c|c|c|c|c|c|c|c|}
\hline \multirow{2}{*}{$\begin{array}{l}\text { Sl. } \\
\text { No. }\end{array}$} & \multirow{2}{*}{$\begin{array}{c}\text { Name of the } \\
\text { Mandal }\end{array}$} & \multicolumn{3}{|c|}{ Primary } & \multicolumn{3}{|c|}{ Upper Primary } & \multicolumn{3}{|c|}{ Total } \\
\hline & & Govt. & Private & All & Govt. & Private & All & Govt. & Private & All \\
\hline 1 & Tenali & 8 & 15 & 10 & 6 & 12 & 9 & 8 & 14 & 10 \\
\hline 2 & $\begin{array}{c}\text { Amadala- } \\
\text { valasa }\end{array}$ & 10 & 20 & 13 & 8 & 11 & 10 & 10 & 16 & 12 \\
\hline & Total & 9 & 17 & 11 & 7 & 12 & 9 & 9 & 15 & 11 \\
\hline
\end{tabular}

Source: Computed from Primary Data.

Table 6: Infrastructural Facilities of the Schools

\begin{tabular}{|c|c|c|c|c|c|c|c|c|c|c|}
\hline \multirow{2}{*}{$\begin{array}{l}\text { Sl. } \\
\text { No. }\end{array}$} & \multirow{2}{*}{ Facilities } & \multicolumn{3}{|c|}{ Government } & \multicolumn{3}{|c|}{ Private } & \multicolumn{3}{|c|}{ Total } \\
\hline & & Yes & No & Total & Yes & No & Total & Yes & No & Total \\
\hline 1 & Pucca Building & 288 (93.5) & $20(6.5)$ & 308 (100.0) & 68 (94.4) & $4(5.6)$ & $72(100.0)$ & $356(93.7)$ & $24(6.3)$ & $380(100.0)$ \\
\hline 2 & Compound Wall & $195(63.3)$ & $113(36.7)$ & 308 (100.0) & 68 (94.4) & $4(5.6)$ & $72(100.0)$ & $263(69.2)$ & $117(30.8)$ & 380 (100.0) \\
\hline 3 & Drinking water & 282 (91.6) & $26(8.4)$ & 308 (100.0) & 68 (94.4) & $4(5.6)$ & $72(100.0)$ & $350(92.1)$ & $30(7.9)$ & 380 (100.0) \\
\hline 4 & Toilet & $271(88.0)$ & $37(12.0)$ & $308(100.0)$ & $68(94.4)$ & $4(5.6)$ & $72(100.0)$ & $339(89.2)$ & $41(10.8)$ & $380(100.0)$ \\
\hline 5 & $\begin{array}{l}\text { Separate girls } \\
\text { toilet }\end{array}$ & $266(86.4)$ & 42 (13.6) & $308(100.0)$ & 63 (87.5) & $9(12.5)$ & $72(100.0)$ & $329(86.6)$ & $51(13.4)$ & 380 (100.0) \\
\hline 6 & Electricity & 298 (96.8) & $10(3.2)$ & $308(100.0)$ & $68(94.4)$ & $4(5.6)$ & $72(100.0)$ & 366 (96.3) & $14(3.7)$ & $380(100.0)$ \\
\hline 7 & $\begin{array}{c}\text { Teaching learning } \\
\text { materials }\end{array}$ & $296(96.1)$ & $12(3.9)$ & $308(100.0)$ & $68(94.4)$ & $4(5.6)$ & $72(100.0)$ & 364 (95.8) & $16(4.2)$ & $380(100.0)$ \\
\hline 8 & Library & $281(91.2)$ & $27(8.8)$ & $308(100.0)$ & $68(94.4)$ & $4(5.6)$ & $72(100.0)$ & 349 (91.8) & $31(8.2)$ & $380(100.0)$ \\
\hline 9 & Play ground & $211(68.5)$ & $97(31.5)$ & $308(100.0)$ & $68(94.4)$ & $4(5.6)$ & 72 (100.0) & 279 (73.4) & $101(26.6)$ & $380(100.0)$ \\
\hline 10 & Play materials & 251 (81.5) & 57 (18.5) & 308 (100.0) & $68(94.4)$ & $4(5.6)$ & $72(100.0)$ & 319 (83.9) & $61(16.1)$ & $380(100.0)$ \\
\hline
\end{tabular}

Source: Computed from Primary Data.

kind of distribution has been observed in primary schools and upper primary schools. In primary schools the pupil teacher ratio is highest in private schools (1:17) followed by government schools (1:9) and together (1:11). In upper primary schools the pupil teacher ratio is highest in private schools (1:12) followed by government schools (1:7) and together (1:9). From the Table 5, it can be observed that the PTR in absolute terms is higher in private schools than in government schools in the sample Mandals. The higher PTR has been observed in private schools rather than government schools in primary and upper primary schools (Table 5).

\section{Infrastructure Facilities}

The infrastructural facilities in the selected schools are inferred that the Government schools 93.5 percent selected schools have pucca buildings while in private school 94.4 percent selected schools have pucca buildings respectively. Schools having compound wall in government schools are 63.3 percent whereas in private school 94.4 percent selected schools have the compound wall. In government school, 91.6 percent schools have drinking water facilities while in private schools 94.4 percent schools have drinking water facilities. Again 88.0 selected government schools toilet facilities and in private schools having toilet facilities are 94.4 percent respectively. Selected schools having toilet facilities for girls in government and private schools are 86.4 percent and 87.5 percent respectively. The table also reveals that 96.8 percent and 94.4 percent 
schools in government and private schools have electricity facility. All selected schools in government and private schools 96.1 percent and 94.4 percent have Teaching-Learning materials. All the selected schools in government and private have separate library for students 91.2 percent and 94.4 percent respectively. Playground facility in government and private schools is 68.5 percent and 94.4 percent respectively. In private schools, the highest numbers of schools have play materials for students which are 94.4 percent in comparison to other Mandal i.e. 81.5 percent respectively (Table 6).

\section{Learning - Quality Indicators}

Table 7 shows teacher's response on quality indicators in the selected schools of sample Mandals. According to the table in Tenali Mandal, 96.1 percent teachers view that the teaching learning materials and curriculum prepared for students are equally useful for both girls and boys. Against this view, only 3.9 percent teachers reply that TLM and curriculum are not equally useful for both girls and boys. In Amadalavalasa Mandal, 97.7 percent teachers view that the teaching learning materials and curriculum prepared for students are equally useful for both girls and boys. Against this view, only 2.3 percent teachers reply that TLM and curriculum are not equally useful for both girls and boys. In Tenali Mandal, TLMs used for teaching equally represent both male and female, according to 96.6 percent teachers. Only 3.4 percent teachers reply in negative about this statement. From the Amadalavalasa Mandal, 93.6 percent TLMs used for teaching equally represent both male and female. In the same way, 6.4 percent teachers reply negatively about this statement. According to the table, 79.2 percent teachers respond positively that writings of both male and female writers are equally included in the

Table 7: Teacher's Response on Learning - Quality Indicators

\begin{tabular}{|c|c|c|c|c|}
\hline Sl. No. & Response & Yes & No & Total \\
\hline \multicolumn{5}{|c|}{ Whether TLMs and curriculum prepared for students are equally useful for both girls and boys or not? } \\
\hline 1 & Tenali & 199(96.1) & $8(3.9)$ & $207(100.0)$ \\
\hline 2 & Total & $368(96.8)$ & $12(3.2)$ & $380(100.0)$ \\
\hline \multicolumn{5}{|c|}{ Whether the TLMs used for teaching equally represents both male and female or not? } \\
\hline 1 & Tenali & 200(96.6) & $7(3.4)$ & $207(100.0)$ \\
\hline 2 & Total & $362(95.3)$ & $18(4.7)$ & $380(100.0)$ \\
\hline \multicolumn{5}{|c|}{ Whether the writings of male and female writers are equally included in the textbooks or not? } \\
\hline 1 & Tenali & $161(77.8)$ & $46(22.2)$ & $207(100.0)$ \\
\hline \multirow[t]{2}{*}{2} & Amadalavalasa & $140(80.9)$ & $33(19.1)$ & $173(100.0)$ \\
\hline & Total & $301(79.2)$ & $173(100.0)$ & $380(100.0)$ \\
\hline \multicolumn{5}{|c|}{ Teacher's engagement in other activities except teaching } \\
\hline 1 & Tenali & $116(56.0)$ & $91(44.0)$ & $207(100.0)$ \\
\hline \multirow[t]{2}{*}{2} & Amadalavalasa & $173(100.0)$ & - & $173(100.0)$ \\
\hline & Total & $289(76.1)$ & $91(23.9)$ & $380(100.0)$ \\
\hline \multicolumn{5}{|c|}{ Remedial classes taken by teachers for educationally weak students } \\
\hline 1 & Yes & $204(98.6)$ & $166(96.0)$ & $370(97.4)$ \\
\hline \multirow[t]{2}{*}{2} & No & $3(1.4)$ & $7(4.0)$ & $10(2.6)$ \\
\hline & Total & $207(100.0)$ & $173(100.0)$ & $380(100.0)$ \\
\hline \multicolumn{5}{|c|}{ Whether teachers use TLMs in the classroom or not? } \\
\hline 1 & Tenali & $207(100.0)$ & - & $207(100.0)$ \\
\hline
\end{tabular}

Source: Computed from Primary Data. 
textbooks. On the other hand, 20.8 percent teachers are against this view. In Tenali Mandal, 77.8 percent teachers respond positively and in Amadalavalasa Mandal is 80.9 percent. Moreover, 91.1 percent teachers view that languages and pictures used in the textbooks are free from gender biasness. On the other hand, 8.9 percent teachers are against this view. In Tenali Mandal 89.9 percent teachers respond positively and Amadalavalasa Mandal it is 92.5 percent. Out of the total selected teachers in Tenali Mandal, 56.0 percent teachers have replied that they are engaged in other activities except teaching. On the other hand, 44.0 percent teachers have responded negatively. From the total selected teachers in Amadalavalasa Mandal, 100.0 percent teachers have responded that they are engaged in other activities except teaching. Similarly in Tenali Mandal, 98.6 percent teachers take remedial classes for the educationally weaker students and only 1.4 percent teachers do not take such classes. From the Amadalavalasa Mandal, 96.0 percent teachers take remedial classes for the educationally weaker students and 4.0 percent teachers do not take such classes. Further, the table reveals that 100 percent students have replied positively that teachers use teaching learning materials in the classrooms in the both Mandals.

\section{Provisions}

Table 8 indicates that teacher's response on Mid Day Meal Scheme adopted by the government in the schools. In Tenali Mandal, in view of 90.3 percent of teachers the Mid-Day Meal scheme has the positive impact on the quality of education. On the other hand, 9.7 percent teachers have replied that the scheme does not have any impact on the quality of education. From Amadalavalasa Mandal, 74.6 percent teachers have said that the Mid-Day Meal scheme has an impact on the quality of education. On the other hand, 25.4 percent teachers have replied that the scheme does not have any impact on the quality of education. From the table, it is interpreted that Mid-Day Meal Scheme according to the majority of teachers has not contributed to the quality education among students. Rather it has created a chaotic situation in the process of school education. In their view, students become uninterested in the classes as they are more motivated to have food during school hours. The classes after taking meal become boring for the students as they feel drowsy. Against this, in the view of some teachers, Mid-Day Meal scheme has motivated the students to come to school. Thus, it has helped in increasing the enrolment and retention of the students in the schools.

Table 8 infers teacher's response on the utilization of funds and distribution of scholarship for girls in the selected schools of selected sample Mandals. According to the table, in Tenali Mandal, only 8.7 percent teachers have viewed that separate funds are utilised specifically for girls but 91.3 percent teachers are against this view. In Amadalavalasa Mandal, 5.8 percent teachers have viewed that separate funds are utilised specifically for girls but 94.2 percent teachers are against this view. In Amadalavalasa Mandal, 54.5 percent of teachers

Table 8: Teacher's Response on Provisions

\begin{tabular}{|c|c|c|c|c|}
\hline Sl. No. & Name of the Mandal & Yes & No & Total \\
\hline \multicolumn{5}{|c|}{ Whether there is any provision for Mid-Day Meal } \\
\hline 1 & Tenali & $187(90.3)$ & $20(9.7)$ & $207(100.0)$ \\
\hline \multirow[t]{2}{*}{2} & Amadalavalasa & $129(74.6)$ & $44(25.4)$ & $173(100.0)$ \\
\hline & Total & $316(83.2)$ & $64(16.8)$ & $380(100.0)$ \\
\hline \multicolumn{5}{|c|}{ Whether separate funds are utilized specifically for girls or not? } \\
\hline 1 & Tenali & $18(8.7)$ & $189(91.3)$ & $207(100.0)$ \\
\hline \multirow[t]{2}{*}{2} & Amadalavalasa & $10(5.8)$ & $163(94.2)$ & $173(100.0)$ \\
\hline & Total & $28(7.4)$ & $352(92.6)$ & $380(100.0)$ \\
\hline \multicolumn{5}{|c|}{ Whether there is any provision for girls scholarship or not? } \\
\hline 1 & Tenali & - & - & - \\
\hline \multirow[t]{2}{*}{2} & Amadalavalasa & $207(54.5)$ & $173(45.5)$ & $380(100.0)$ \\
\hline & Total & $207(54.5)$ & $173(45.5)$ & $380(100.0)$ \\
\hline
\end{tabular}

Source: Computed from Primary Data. 
have responded positively and against 45.5 percent of teachers have responded negatively about provision for girl's scholarship.

Table 9 shows student's response on getting free textbooks and uniform from the school. It shows that 100 percent students have replied positively in getting both free textbooks and uniform from the school in both the Mandals. Table 9 indicates student's response on getting scholarship from the school. In Tenali Mandal, it shows that only 1.4 percent students have got the scholarship and 98.6 percent student have replied negatively stating that they have not got any scholarship from the school. In Amadalavalasa Mandal, 0.9 percent students have got the scholarships and 99.1 percent students have replied in negative stating that they have not got any scholarships from the school.

\section{Committees}

Table 10 shows teacher's response on the functioning of SMC in the schools of selected Mandals. The Table reveals that in Tenali Mandal, 99.0 percent teachers are satisfied with the functioning of School Management Committee against which 1.0 percent teachers have replied that they are not satisfied with the functioning of SMC. In Amadalavalasa Mandal, 97.7 percent teachers are satisfied with the functioning of School Management Committee against which 2.3 percent teachers have replied that they are not satisfied with the functioning of SMC.

Table 10 shows teacher's response on gender related issues of School Management Committee in the selected schools of sample Mandals. In Tenali Mandal, it shows that 97.1 percent teachers have

Table 9: Student's Response on Provisions

\begin{tabular}{|c|c|c|c|c|}
\hline Sl. No. & Response & Yes & No & Total \\
\hline \multicolumn{5}{|c|}{ Whether the student get free textbook from the school or not? } \\
\hline 1 & Tenali & $414(100.0)$ & - & $414(100.0)$ \\
\hline 2 & Amadalavalasa & $346(100.0)$ & - & $346(100.0)$ \\
\hline \multicolumn{5}{|c|}{ Whether the student get uniform from the school or not? } \\
\hline 1 & Tenali & $414(100.0)$ & - & $414(100.0)$ \\
\hline \multicolumn{5}{|c|}{ Whether the Student Gets Scholarship or Not } \\
\hline 1 & Tenali & $6(1.4)$ & $408(98.6)$ & $414(100.0)$ \\
\hline \multirow[t]{2}{*}{2} & Amadalavalasa & $3(0.9)$ & $343(99.1)$ & $346(100.0)$ \\
\hline & Total & $9(1.2)$ & $751(98.8)$ & $760(100.0)$ \\
\hline
\end{tabular}

Source: Computed from Primary Data.

Table 10: Teacher's Response on Committees

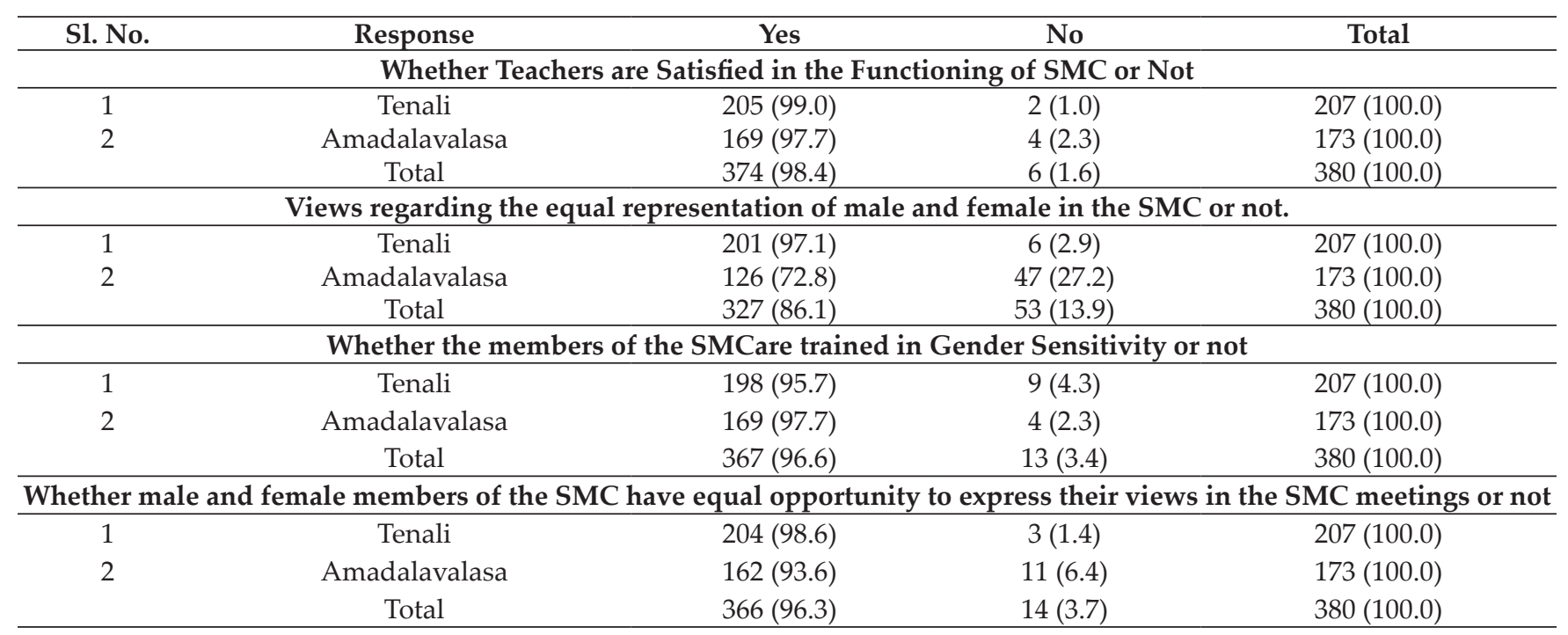

Source: Computed from Primary Data. 
said that for equal representation of male and female in the functioning of the School Management Committee while only 2.9 percent teachers have replied in the negative. In Amadalavalasa Mandal, 72.8 percent teachers have replied positively on equal representation of male and female in the functioning of the School Management Committee whereas 27.2 percent teachers have replied in negative. The Table also indicates that in Tenali Mandal, 95.7 percent of teachers have replied that the members of the SMC are trained in gender sensitivity, but 4.3 percent teachers have replied that members of the SMC are not trained in gender sensitivity. In Amadalavalasa Mandal, 97.7 percent teachers have viewed that both male and female members have equal opportunity to express their view in the meetings of the SMC. On the other hand, only 2.3 percent teachers have replied in the negative about this view. Table concludes that in Tenali Mandal, 98.6 percent SMC have equal opportunity to express their views in the SMC meetings or not while only 1.4 percent SMC have equal opportunity in negative. In Amadalavalasa Mandal, 93.6 percent SMC have equal opportunity to express their views in the SMC meetings or not whereas 6.4 percent teacher's reply negatively.

Table 11 shows teacher's response on PTS meetings in the selected schools of selected Mandals. In Tenali Mandal, 92.8 percent teachers respond that PTS meetings are held in their school while 7.2 percent teachers view that PTS meetings are not held in their schools. In Amadalavalasa Mandal, 67.1 percent teachers respond that PTS meetings are held in their school although 32.9 percent teachers view that PTS meetings are not held in their schools. Table 11 shows teacher's response on frequencies of PTS meetings held in the selected schools of sample Mandals. According to the table in Tenali Mandal, 73.4 percent teachers have replied that Parent-Teacher-Student meeting is held in their schools once in a year, 19.3 percent teachers have replied that for twice in a year and 7.3 percent teachers have replied that for more than twice in a year that PTS meetings are held in their schools. In Amadalavalasa Mandal, 44.8 percent teachers have replied that Parent-Teacher-Student meeting is held in their schools once in a year, 35.3 percent teachers have replied that for more than twice in a year and 19.8 percent teachers have replied that for twice a year that PTS meetings are held in their schools.

Table 11 shows Teacher's response on attendance of parents in the Parent- Teacher-Student meetings held in their schools. The Table indicates that in Tenali Mandal, 54.7 percent teachers have replied that for more than half of the parents are present in the meetings. Similarly 15.6 percent teachers have replied that less are present another 13.5 percent teachers have replied that half of the parents are present in the PTS meetings. In the table it is seen that 10.4 percent of teachers have viewed that all

Table 11: Teacher's Response on PTS Meetings

\begin{tabular}{|c|c|c|c|c|}
\hline S1. No. & Response & Tenali & Amadalavalasa & Total \\
\hline \multicolumn{5}{|c|}{ Whether PTS meetings are held or not held in the School } \\
\hline 1 & Yes & $192(92.8)$ & $116(67.1)$ & $308(81.1)$ \\
\hline \multirow[t]{2}{*}{2} & No & $15(7.2)$ & $57(32.9)$ & $72(18.9)$ \\
\hline & Total & $207(100.0)$ & $173(100.0)$ & $380(100.0)$ \\
\hline \multicolumn{5}{|c|}{ Frequencies of PTS Meetings } \\
\hline 1 & Once a year & $141(73.4)$ & $52(44.8)$ & $193(62.7)$ \\
\hline 2 & Twice a year & $37(19.3)$ & $23(19.8)$ & $60(19.5)$ \\
\hline \multirow[t]{2}{*}{3} & More than twice & $14(7.3)$ & $41(35.3)$ & $55(17.9)$ \\
\hline & Total & $192(100.0)$ & $116(100.0)$ & $308(100.0)$ \\
\hline \multicolumn{5}{|c|}{ Attendance of Parents in PTS Meetings } \\
\hline 1 & Very Less Present & $30(15.6)$ & $50(43.1)$ & $80(26.0)$ \\
\hline 2 & Less than Half Present & $11(5.7)$ & $31(26.7)$ & $42(13.6)$ \\
\hline 3 & Half Present & $26(13.5)$ & $23(19.8)$ & $49(15.9)$ \\
\hline 4 & More than Half Present & $105(54.7)$ & - & $105(34.1)$ \\
\hline \multirow[t]{2}{*}{5} & All Present & $20(10.4)$ & $12(10.3)$ & $32(10.4)$ \\
\hline & Total & $192(100.0)$ & $116(100.0)$ & $308(100.0)$ \\
\hline
\end{tabular}

Source: Computed from Primary Data. 
parents are present in these meetings. Lastly, 5.7 percent teachers have replied that less than half the parents are present in the PTS meetings. In Amadalavalasa Mandal, 43.1 percent of teachers have said that fewer parents attend the meetings. Alike, 26.7 percent teachers have replied that less than half the parents are present and another 19.8 percent teachers have replied that half for half present in the PTS meetings. Lastly, 10.3 percent teachers have viewed that all present in the PTS meetings.

\section{CONCLUSION}

The higher PTR has been observed in private schools than government schools in primary and upper primary schools. Around 90 per cent schools have infrastructural facilities in Tenali Mandal, while it is 80 per cent in Amadalavalasa Mandal. According to primary data, above 90 percent teachers have viewed that the teaching learning materials and curriculum prepared for students are equally useful for both girls and boys. The study reveals that 100 percent students have responded positively regarding the use teaching learning materials in the classrooms in both Mandals. It is observed that although most of the students understand the classroom teaching without any difficulty, some students face certain difficulties in learning the subjects in a single class and they have informed the teachers about their problems.

In Tenali Mandal, in the view of 90.3 per cent of teachers the Mid-Day Meal scheme has the positive impact on the quality of education. From Amadalavalasa Mandal, 74.6 per cent teachers have said that the Mid-Day Meal scheme has an impact on the quality of education. Student's response shows that 100 percent students are getting both free textbooks and uniform from the school in both the Mandals. Around 90.0 per cent students are not getting any scholarship. The result reveals that in both sample Mandals, 95.0 percent teachers are satisfied with the functioning of School Management Committee. Further, 95.5 percent of teachers have repplied that the members of the SMC are trained in gender sensitivity issues and have equal opportunity to express their views in the SMC meetings for male and female members. In Tenali Mandal, 92.8 percent teachers have responded positively that PTS meetings are held in their school while in Amadalavalasa Mandal, 67.1 percent teachers have responded positively that PTS meetings are held in their school. Parent-TeacherStudent meeting is held in their schools once in a year and more than half of the parents are present in the PTS meetings.

\section{REFERENCES}

Agrawal, T. 2013. Educational attainment in educationally backward states of India: some implications for the right to education act. International Journal of Education Economics and Development, 4(1): 89-99.

AHD. 2012. ASEAN Human Rights Declaration, The Association of South Asian Nations, Jakarta. http://www. asean.org/

Assembly, U.G. 1966. International covenant on economic, social and cultural rights. United Nations, Treaty Series, 993(3): 2009-57.

Banerjee, R. and Arora, S. 2013. A Study on India's the Right to Education Act: Overcoming Social \& Economic Challenges, The Asian Conference on Education, Official Conference Proceedings, Osaka, Japan.

Bhan, S. and Rodricks, S. 2012. Indian perspective on child's right to education. Procedia-Social and Behavioral Sciences, 69: 367-376.

Calland, L.N.A.R. 2010. Making the access to information law work: The challenges of implementation, New York: The Carter Center.

CEDAW. 1979. The Convention on the Elimination of All Forms of Discrimination against Women, United Nations Entity for Gender Equity and Women Empowerment, http:// www.un.org/womenwatch/daw/cedaw/

Chauhan, A. and Sati, A. 2016. Prospects, Challenges and Achievements of Right to Education in Uttarakhand, India. Research Journal of Educational Sciences, 4(5): 1-4.

Cheruvalath, R. 2015. Is the right of children to free and compulsory education act really beneficial to the poorer children in India? An analysis with special reference to the admission of poorer children in public unaided schools. Education 3-13, 43(6): 621-629.

Craissati, D., Devi Banerjee, U., King, L., Lansdown, G. and Smith, A. 2007. A human rights based approach to education for all. United Nations Children's Fund.

CRC, 1989. Convention on the Rights of the Child, United Nations Human Rights, http://www.ohchr.org

Dutta, I. and Khan, M.A. 2017. Educational and Social Inclusion of Children Admitted Under RTE Quota: A survey of private schools of Bhopal. MIER Journal of Educational Studies, Trends and Practices, 6(2): 138-154.

ECHR. 1952. European Convention on Human Rights, European Court of Human Rights, https://www.echr.coe.int/

Ernst and Young. 2011. Right to education: role of the private sector, Ernst \& Young Pvt. Ltd, Kolkata. 
Hussain, R., Butt, T.I. and Abbas, Z. 2014. Right to Education: Leads to Betterment. International Journal of Humanities and Social Science Invention, 3(7): 15-17.

Jha, P. and Parvati, P. 2010. Right to Education Act 2009: critical gaps and challenges. Economic and Political Weekly, 45(13): 20-23.

Kamalakar, G. and Bhojanna, N. 2012. Reservation in Private Schools under the Right to Education Act: Model for Implementation. International Journal of Management Research and Reviews, 2(6): 958-966.

Kaushal, M. 2012. Implementation of Right to Education in India: Issues and Concerns. Journal of Management and Public Policy, 4(1): 42-48.

Mahajan, G. 2016. Implementation of Right to Education Act in context of Drinking Water and Sanitation Facilities: A Case Study of Himachal Pradesh. International Journal of Informative \& Futuristic Research, 4(2): 5268-5274.

Malakar, R. and Mahato, A. 2015. Implementation Status of Right to Education (RTE) Act 2009 in Tripura: A Critical Analysis. MGIRED Journal, 2(1): 90-100.

Mehendale, A., Mukhopadhyay, R. and Namala, A. 2015. Right to Education and inclusion in private unaided schools. Economic \& Political Weekly, 50(7): 43-51.

Nalini, J. 2003. Constitutional Amendment to Make Education a Fundamental Right - Issues for a Follow-up Legislation, National Institute of Educational Planning and Administration, New Delhi.
Reddy, A.N. and Sinha, S. 2010. School dropouts or pushouts? Overcoming barriers for the Right to Education. Research Monograph No 40. National University of Educational Planning and Administration, New Delhi and Centre for International Education, University of Sussex, UK.

RTE Forum, 2009, Vision Paper, Right to Education Forum, New Delhi.

Sarin, A. and Gupta, S. 2014. Quotas under the Right to Education. Economic \& Political Weekly, 49(38): 65-72.

Soni, R.B.L. 2013. Status of Implementation of RTE Act-2009 in Context of Disadvantaged Children at Elementary Stage, Department of Elementary Education, National Council of Educational Research and Training, New Delhi.

Sucharita, V. and Sujatha, K. 2019. Engaging with social inclusion through RTE: a case study of two private schools in Delhi, India. International Journal of Inclusive Education, 23(3): 313-327.

Thakur. 2014. Study the Awareness of Trained School Teachers in Relation to RTE Act at Elementary Level. American International Journal of Research in Humanities, Arts and Social Sciences, 6(1): 67-71.

UDHR. 1948. The Universal Declaration of Human Right (UDHR), UN website, http://www.un.org/en/documents/ udhr/index.shtml.

UNESCO. 1960. Convention against Discrimination in Education. United Nations Educational Scientific and Cultural Organization. http://portal.unesco.org/ 